\title{
PENTINGNYA KECERDASAN DALAM PENINGKATAN PROFESIONALISME SEKRETARIS DALAM MELAKSANAKAN TUGAS
}

\author{
O le h :WALUYO: \\ (waluyop4tkbispargmail.com)
}

\begin{abstract}
Abstrak
Jabatan dan profesi sekretaris sering mendapatkan banyak pandangan dan sorotan negatif dalam lingkungan masyarakat, sekretaris merupakan jabatan yang sangat penting dalam sebuah organisasi. Pimpinan organisasi tidak akan dapat menyelesaikan pekerjaan dan tugas-tugasnya seharihari, tanpa bantuan seorang sekretaris. Posisi sekretaris sudah semakin strategis, tidak hanya sebagai penerima telepon, menulis surat, ataupun menjadwalkan pertemuan pimpinan, tetapi seringkali seorang sekretaris sebagai ujung tombak organisasi atau perusahaan, sehingga dituntut untuk mampu mengambil sikap dan keputusan ketika pimpinan tidak sedang berada di kantor. Dengan berkembangnya tugas-tugas seorang sekretaris, dari tugas rutin sesuai dengan penjabaran pekerjaannya menjadi tugas yang kreatif, dituntut adanya kemauan yang keras dari pribadi sekretaris dalam mengembangkan wawasan, keterampilan yang khusus, interaksi, dan perubahan sikap sesuai dengan tuntutan dan perkembangan organisasi tempatnya bekerja untuk menjadi sekretaris yang profesional. Dalam hal ini, termasuk kecerdasan emosi sebagai dasar yang penting dalam pengembangan kepribadian dan peningkatan profesionalisme sekretaris.
\end{abstract}

\section{Pendahuluan}

$\mathrm{P}$ impinan menuntut sekretaris untuk dapat membantu melaksanakan tugas tugasnya dengan baik. Beragamnya tuntu tan pimpinan, diharapkan sekretaris dapat bertindak dan berpikir kreatif, inovatif, cepat tanggap, dan mampu mengatasi masalah-masalah yang dihadapi dalam menjalankan tugasnya sehari-hari. Meskipun tuntutan pimpinan terlihat berat beban tugas, seorang sekretaris profesional memiliki kesanggupan dan kesiapan dalam menyelesaikan setiap permasalahan yang dihadapi.Sebagai ujung tombak pimpinan, sekretaris harus siap menghadapi setiap permasalahan, sebelum masalah itu benar-benar harus dihadapi dan diselesaikan pimpinan. Tugas dan tanggung jawab sekretaris tidak lagi terbatas pada menerima telepon, menghadapi tamu, menangani surat, dan mengatur jadwal rapat, lebih luas lagi seorang sekretaris mempunyai tugas untuk dapat mengambil keputusan dan memimpin bawahan pada saat pimpinan tidak berada di tempat. Bahkan sejalan dengan semakin berkembangnya organisasi, seorang sekretaris harus dapat mengambil keputusan, sebagaimana yang harus dilakukan oleh seorang pimpinan, jika sekretaris tersebut benarbenar telah memiliki kepercayaan penuh dari pimpinan.Sehingga seorang sekretaris profesional harus dapat memaknai tugas dan tanggung jawabnya secara menyeluruh, karena selain sebagai ujung tombak, sekretaris dapat dikatakan pula sebagai pengganti, tangan kanan ketika pimpinan tidak berada di lingkungan kerja. 
$\mathrm{S}$ ekretaris merupakan profesi yang dinamis dan senantiasa berkembang mengikuti tuntutan bidang pekerjaan dan organisasinya.Agar dalam melaksanakan tugas dan pekerjaannya dapat berhasil dan bermanfaat, sekretaris harus dapat mengembangkan kemampuan pribadinya.Sekretaris dituntut untuk belajar dan terus belajar guna meningkatkan wawasan dan keterampilan sesuai dengan tuntutan lingkungan pekerjaannya dan sikap sehari-hari dalam menghadapi dan menyelesaikan pekerjaannya. Dengan bertambahnya wawasan dan keterampilan, sekretaris akan semakin kompeten dibidang pekerjaannya. Aspek lain yang perlu diperhatikan dalam membentuk sekretaris yang memiliki kompetensi dan profesionalisme adalah kecerdasan emosi. Kecerdasan emosi turut andil dalam membentuk dan mengembangkan pribadi sekretaris sehingga menjadi seorang sekretaris yang profesional.Berdasarkan tuntutan profesi itulah, penulis bermaksud menguraikan lebih lanjut tentang "Pentingnya Kecerdasan Emosi dalam Peningkatan Profesionalisme Sekretaris.

\section{Pengertian dan Peran Masa Depan Sekretaris}

Sekretaris berasal dari bahasa Belanda scretaries atau dalam bahasa Inggris secretary yang berasal dari bahasa Latin secretum yang berarti rahasia. Sesuai dengan asal katanya sekretaris berarti seseorang yang harus dapat menyimpan rahasia (Prayudi Atmosudirdjo, 1982: 63).

$\mathrm{D}$ alam menjalankan tugasnya sekretaris tentunya dihadapkan pada pekerjaan-pekerjaan yang kerahasiaannya harus dipegang kuat-kuat. Sekretaris harus dapat memilah-milah informasi atau masalah-masalah yang dapat disebar luaskan kepada pihak lain dan informasi atau masalah-masalah yang tidak boleh disebarluaskan kepada pihak lain. Bocornya rahasia organisasi atau tidak pandai-pandainya seorang sekretaris memegang rahasia akan menghambat bahkan kemungkinan besar menutup perluasan networking perusahaan. Dengan kata lain, seorang sekretaris harus dapat mengendalikan diri, karena apabila sekretaris terbawa emosi, kemungkinan tidak dapat menjaga kerahasiaan perusahaan, sebagai akibatnya dapat menurunkan pamor perusahaan. Untuk dapat mengendalikan diri, fleksibel, dan adaptable, kecerdasan emosi mutlak diperlukan dan dapat mempengaruhi profesionalisme sekretaris.

Louis C. Nanasay dan William Selden menyebutkan pengertian sekretari : an office employee who has more responsible position than a stenographer and who duties usually include taking and transcribing dictation; dealing with the public by answering the telephone, meeting callers ang making appointments; and maintaining or filing records, 


\section{letter etc. A secretary frequently acts as an administrative assistant or junior excecutive}

(seorang pegawai kantor yang memiliki kedudukan yang lebih bertanggung jawab daripada seorang stenografer, dan tugas-tugasnya biasanya meliputi pengambilan dan penyalinan dikte; membuat perjanjian, dan memelihara atau mengarsipkan warkat-warkat, surat-surat dan lain-lain. Seorang sekretaris bertindak sebagai seorang pembantu administrasi atau pimpinan muda).

$\mathrm{D}$ ilihat dari perkembangan tugas sekretaris, peran sekretaris pada masa yang akan datang selain melaksanakan peran strategis, peran teknis, dan peran pendukung, sekretaris juga berperan sebagai pimpinan muda. Dalam mendukung kesuksesan kariernya sebagai sekretaris masa depan, harus memiliki kemampuan dan tanggung jawab manajemen, dalam arti memiliki sifat kepemimpinan dan kemampuan manajerial sebagai syarat mutlak. Untuk mencapai kesuksesan sekretaris dalam berkarier secara profesional dalam bidang kerjanya dan dapat menghadapi tantangan masa depan, kecerdasan emosi mutlak harus dimilikinya.

\section{Profesional dan Profesionalisme Sekretaris}

Drofesional secara harafiah dalam Webster New American Dictionary diartikan sebagai 1 kata sifat yang berhubungan dengan suatu profesi atau karakteristik sebuah profesi.Sedangkan profesionalisme adalah the conduct, aims, or qualities that characterize or mark a profession or a profesional person (perbuatan, atau tujuan, atau kualitas yang berkarakter, atau menunjukkan sebuah profesi atau individu). Seorang sekretaris dalam perjalanan kariernya harus dapat mengerjakan pekerjaannya dengan berkualitas, dapat memahami serta menguasai bidang kerjanya dengan baik, termasuk menghindari konotasi negatif yang akan terlontar melalui pandangan masyarakat yang dinamis mengenai profesi sekretaris. Apalagi sekretaris yang bidang kerjanya sebagai seorang 'sekretaris pribadi', dimana peran seorang 'sekretaris pribadi' bisa merupakan pegawai atau staf dari suatu organisasi atau perusahaan yang mengerjakan kegiatan perkantoran untuk membantu orang tertentu yang bersifat pribadi.

$\mathrm{T}$ etapi peran ini dapat juga diartikan sebagai seorang yang mengerjakan kegiatan perkantoran, tetapi diangkat dan digaji oleh perorangan maka impresi publik yang melontarkan konotasi bahwa seorang yang bekerja seperti itu adalah seorang yang juga 'melayani kebutuhan pribadi' menjadikan kemampuan kecerdasan emosi pribadi seorang sekretaris sangat penting untuk meningkatkan profesionalisme pribadi sekretaris yang 
bersangkutan. Dengan kecerdasan emosi yang dimilikinya dalam menghadapi tantangan dan pekerjaannya dapat diandalkan untuk mempertahankan harga diri dan citra dirinya sebagai seorang sekretaris. Melalui pengasahan kecerdasan emosi, seorang sekretaris dapat mempertahankan komitmen pribadinya dalam melaksanakan tugas sebagai 'sekretaris pribadi', tidak hanya melayani kepentingan pribadi yang berhubungan dengan pekerjaannya, tetapi yang bersangkutanpun harus dapat melayani kepentingan publiknya baik internal maupun eksternal organisasi tanpa terpengaruh oleh dinamika pergeseran pandangan moral masyarakat terhadap profesi seorang sekretaris. Tentu beralasan jika etika sekretaris pada saat melaksanakan tugasnya memiliki peran yang sangat penting untuk dapat diaplikasikan ketika sekretaris harus membina hubungan dengan klien/pelanggannya.(Neni Yulianita, 2003: 4), dimana penerapan etika sekretaris dalam dunia kerja yang nyata memerlukan pendalaman kecerdasan emosi yang baik dari seorang sekretaris terutama dalam menjaga harga diri dan citra diri positif dengan tetap mendapatkan keseimbangan serta prestasi pribadi seorang sekretaris profesional.

\section{Kecerdasan Emosi dan Peningkatan Profesionalisme Sekretaris}

Emosi didefinisikan dalam Oxford English Dictionary sebagai setiap kegiatan atau pergolakan pikiran, perasaan, nafsu; setiap keadaan mental yang hebat atau meluap-luap. Daniel Goleman (1997: 411), menggolongkan secara garis besar sebagai berikut:

a. Amarah; beringas, tersinggung, benci, jengkel, kesal hati, bermusuhan

b. Kesedihan; pedih, sedih, muram, suram, putus asa, mengasihani diri

c. Rasa takut; cemas, takut, gugup, khawatir, waswas

d. Kenikmatan; bahagia, gembira, ringan, puas, riang, senang, terhibur, bangga, rasa puas, rasa terpenuhi

e. Cinta; penerimaan, persahabatan, kepercayaan, kebaikan hati, kasih

f. Terkejut; terkejut, terkesiap takjub, terpana

g. Jengkel; hina, jijik, muak, mual, benci

h. Malu; rasa salah, malu hati, kesal hati, sesal, hina, hati hancur lebur

Banyak peneliti yang berkiblat pada penemuan Paul Ekman dari University of California di San Fransisco yang menyatakan bahwa ekspresi wajah tertentu untuk keempat emosi dasar (takut, marah, sedih, dan senang), dikenali oleh bangsa-bangsa di seluruh dunia dengan budayanya masing-masing (Daniel Goleman, 1995: 412). 
Sebagai ilustrasi emosi, jika kita tempatkan emosi sebagai titik pusat, maka tepi luar "lingkaran emosi" diisi oleh suasana hati, di luar suasana hati ada yang disebutkan temperamen, yaitu keadaan yang dapat memunculkan emosi atau suasana hati tertentu yang dapat membuat seseorang menjadi marah, benci, sedih, putus asa ataupun bahagia.

Sedangkan Kecerdasan Emosi menurut Patricia Patton (1997: 1) adalah dasar pokok dalam membangun hubungan lalu memeprkuat diri kita, serta orang lain untuk menghadapi tantangan, yaitu keseimbangan antara perasaan dan pikiran.

Melalui kecerdasan emosi yang terasah, seorang sekretaris bisa menjalankan tugasnya sebagai ujung tombak pimpinan dengan lebih baik atau secara profesional, dapat menjaga rahasia, melakukan tugasnya sehari-hari, serta memimpin rekan kerja tanpa selalu mengikuti suasana hatinya, walaupun dirinya sedang dalam keadaan marah, benci, sedih, putus asa ataupun bahagia. Seorang sekretaris harus dapat mempertahankan harga dirinya ataupun citra dirinya agar tidak dicap sebagai sekretaris yang pemarah, pencemburu, tidak sabar dalam meng hadapi masalah di lingkungan kerja. Dalam dunia usaha, sangat penting bagi seorang sekretaris untuk dapat mengasah kecerdasan emosinya terutama dalam segi interpersonal relationship, mendeteksi konflik, dan sensivitas kerja (A.B. Susanto, 2001: 22) Sejalan dengan tuntutan pekerjaan seorang sekretaris yang tidak lagi berfungsi hanya sebagai penerima telefon. Tidak hanya dalam jabatan dan peranannya sebagai 'sekretaris pribadi', sekretaris pimpinan, sekretaris direksi, ataupun sekretaris organisasi, ada beberapa kriteria pengembangan kepribadian sekretaris yang sangat memerlukan kecerdasan emosi terutama untuk memperkuat kompetensi interpersonal relationship-nya sebagai ujung tombak perusahaan, sebagai penyelia (supervisor), sebagai penghubung antara pimpinan dan bawahan, sebagai pelaksana tujuan organisasi.

Menurut Patricia Patton (1997:8), kualitas-kualitas batiniah dalam pembentukan kecerdasan emosi dapat dikelola melalui aspek-aspek berikut:

1. Harga diri; merupakan nilai yang sangat penting pada diri kita untuk menghargai keunikan yang kita miliki. Harga diri memberi kekuatan untuk menetapkan serta mempertahankan tujuan-tujuan, bahkan untuk dapat mengenali kemampuan-kemampuan diri sendiri

2. Manajemen diri; tanpa adanya manajemen diri, kita tidak dapat mengenali emosi dan perilaku yang bisa menyeleksi kehidupan melalui suara-suara, ketakutan-ketakutan dan intuisi batiniah 
3. Citra diri Positif; merupakan cerminan dari pandangan diri kita sendiri

4. Keseimbangan Pribadi; adalah perpaduan positif untuk dapat menjalani kehidupan personal dan karier

5. Prestasi Pribadi; melalui keterampilan-ketrampilan yang bisa dikembangkan untuk mengelola emosi-emosi secara efektif, dalam menangani hubungan dengan baik, dalam mengambil keputusan untuk dapat menciptakan situasi yang memuaskan.

Tidak mudah mengenali dan mengen dalikan aspek-aspek di atas, tetapi jika seorang sekretaris dapat mengembangkan kualitas-kualitas batiniah tersebut di atas, pribadi sekretaris yang bersangkutan akan dengan mudah mencapai kesuksesan karier sebagai sekretaris yang profesional. Jika seorang sekretaris menjunjung tinggi harga diri serta citra dirinya dalam masyarakat, tentunya masyarakat tidak akan memandang sebelah mata terhadap profesi sekretaris, terutama 'sekretaris pribadi'. Aspek dasar kecerdasan emosi adalah harga diri dan citra diri. Harga diri menurut Patricia Patton (1997: 64) adalah penghargaan terhadap keunikan penampilan fisik, kemampuan-kemampuan intelektual, kecakapan-kecakapan pribadi, dan kepribadian, yang merupakan parameter yang "membeda kan" kita dari orang lain sebagai individu. Dalam hal ini jika seorang sekretaris ingin dianggap professional, dia harus bisa mengolah ketidak percayaan dirinya karena dirinya memiliki figure yang kecil, melainkan merasa bangga akan keunikan atau kecilnya figure dirinya. Tidak merasa rendah diri karena suaranya agak lebih besar dari kebanyakan sekretaris yang lain, tetapi justru memakai volume suaranya sebagai modal komunikator yang lebih bijaksana dan dewasa.

emampuan-kemampuan intelektual bisa di cerminkan melalui keputusan-keputusan
yang dibuatnya ketika pimpinan tidak berada di tempat, kemampuannya untuk memimpin rekan sekerja sehingga dapat memiliki tim kerja yang kondusif dan kompak. Kecakapan-kecakapan pribadi yang dituntut bagi seorang sekretaris professional tentunya berbeda dari sekretaris pemula, sebagai contoh kemampuan mengetik sepuluh jari, lebih dari150 hentakan per menit, kemampuan menulis dan berbicara dalam bahasa asing, ataupun kemampuannya berkomunikasi dengan pihak intern maupun ekstern yang merupakan hal fatal dalam posisi pembuat keputusan sewaktu pimpinan tidak berada di tempat. 
Menggali lebih dari kata kepribadian yang dimaksud, seorang sekretaris professional menurut Neni Yulianita (2003: 7) haruslah memiliki kepribadian sebagai berikut:
a. Memiliki rasa Percaya Diri (PD) yang kuat
b. Memiliki keterbukaan terhadap orang lain ataupun dari orang lain
c. Menerima kekurangan dirinya dan mampu memperbaikinya
d. Yakin akan kemampuan dirinya untuk dapat mengatasi masalah
e. Menyadari bahwa profesi dipilih merupakan profesi yang tepat bagi dirinya
f. Memahami peran, fungsi, tugas, dan tanggung jawabnya sebagai sekretaris
g. Menerapkan etika profesi sekretaris secara konsekuen dan bertanggung jawab
h. Pendidikan dan keahlian yang dimilikinya sesuai dengan profesinya
i. Mempunyai motivasi yang kuat untuk menjalankan profesinya
j. Memiliki gaya dan performance yang khas/spesifik dan unik

Sedangkan citra diri, menurut Patricia Patton (1997: 118), adalah refleksi apa yang kita lihat dalam diri sendiri. Potret diri kita terpapar dengan kedalaman, pewarnaan, pencahayaan, dan bayangan yang bisa saja menerang, menipu, ataupun mengaburkan harapan sendiri.Seberapapun beratnya masalah yang dihadapi oleh seorang sekretaris, ketika yang bersangkutan berhadapan dengan rekan kerja, yang bersangkutan tidak boleh mengikuti suasana hatinya dengan marah-marah semena-mena di lingkungan kerja, ataupun meratap menangis berlebihan untuk mendapatkan belas kasih lingkungan.

Apalagi jika yang bersangkutan berhubungan dengan pihak luar mewakili pimpinan yang sedang tidak berada di kantor, seorang sekretaris harus bisa mengatur emosinya untuk tidak memperlihatkan masalah yang dihadapi nya, bahkan harus dapat mengatur diri untuk dapat memperlihatkan suasana yang dapat diterima oleh pihak yang dihadapi. Perbedaan antara suasana diri dengan citra diri terkadang menimbulkan pergolakan batin yang dapat merusak pertumbuhan pribadi kita, tetapi dengan pengasahan kecerdasan emosi yang dimaksud, hal ini akan menjadi sesuatu yang memberikan nilai tambah bagi seorang sekretaris dalam menjalani kariernya untuk mencapai jenjang profesi sebagai seorang sekretaris professional. 


\section{Kesimpulan}

1. Profesi sekretaris masa depan menuntut perubahan paradigma masyarakat tentang profesi sekretaris terutama mereka yang mendapatkan kesempatan untuk berperan memegang jabatan 'sekretaris pribadi'.

2. Profesi sekretaris, bukan saja sebagai penerima telefon, tetapi telah berubah menjadi posisi yang berperan strategis, peran teknis, dan peran pendukung, bahkan bertindak sebagai pemimpin muda.

3. Menghadapi konotasi negatif masyarakat tentang profesi sekretaris, diperlukan pengolahan kualitas batiniah melalui aspek-aspek kecerdasan emosi, seperti harga diri, manajemen diri, citra diri positif, keseimbangan pribadi dan prestasi pribadi.

4. Dengan berpegang pada harga diri dan citra diri sebagai dasar pokok kecerdasan emosi, seorang sekretaris dapat berkariernya dengan baik menjadi seorang sekretaris profesional. 


\section{DAFTAR PUSTAKA}

Asmara, Budiman. Penuntun Praktis Sekretaris Pribagi, Jakarta: Balai Aksara.

Bratawidjaja, Thomas Wiyasa. 1996. Sekretaris Profesional. Jakarta: PT. Pustaka Binaman Pressindo.

Goleman, Daniel. 1996. Emotional Intelligence. Jakarta: Gramedia.

Patton, Patricia. 1998. Kecerdasan Emotional Landasan. Jakarta: Mitra Media. 1999. Kecerdasan Emosional Keterampilan Kepemimpinan. Jakarta: Mitra Media.

Sedarmayanti. 1997. Tugas dan Pengembangan Sekretaris. Bandung: Mandar Maju.

Susanto, A.B. 2001. Secretary \& Beyond, Metamorphosis of Secretary Profession. Jakarta: The Jakarta Consulting Group. 
